\title{
AN UNUSUAL NEW SPECIES OF GUATTERIA (ANNONACEAE) FROM FRENCH GUIANA AND ADJACENT BRAZIL (AMAPÁ)
}

\author{
UWE SCHARF ${ }^{1}$, PAUL J.M. MAAS ${ }^{2} \&$ MARIE FRANCOISE PRÉVOST²
}

\begin{abstract}
SUMMARY
During a taxonomic treatment of Annonaceae for the Flora of the Guianas project, an unusual new species of Guatteria Ruiz \& Pav., G. anteridifera from French Guiana and Amapá in Brazil (Northern South America) was found and described herein.
\end{abstract}

Key words: Annonaceae, Guatteria, tropical South America, French Guiana, taxonomy.

\section{INTRODUCTION}

Of the Neotropical genera of Annonaceae, Guatteria Ruiz \& Pav. is by far the largest. Currently about 400 names and about 290 species of Guatteria are recognised (Erkens 2007). The genus is easily recognised by the combination of axillary flowers/inflorescences with clearly visible articulation on the pedicel, an apocarpous fruit of stipitate monocarps, and an impressed primary vein on the upper side of the leaf. Due to the scattered distribution of the individuals in the distribution area and the low number of individuals per unit area (own and other researcher's observation in the field), it is likely that the actual number may greatly exceed this. Individuals of to date unknown species are easy to miss if they grow away from streets, paths, rivers, field stations, and settlements. Since the generic treatment of R.E. Fries $(1939,1955,1959)$ and some additional publications containing new species (Fries 1941, 1948b, 1952, 1953), only accounts covering part of the genus, in regional floras and checklists, have appeared (e.g., Jansen-Jacobs 1976, Johnson \& Murray 1990, Steyermark et al. 1995, Boggan et al. 1997, Ribeiro et al. 1999, Hollowell et al. 2001, Maas \& Maas-van de Kamer 2002, Erkens 2007). Therefore an updated revision of this species-rich and ecologically diverse but morphologically homogeneous, and thus taxonomically challenging genus is needed. A recent revision can only be approached on a regional basis. The Flora of the Guianas project, coordinated by the Utrecht branch of the National Herbarium of the Netherlands, offered the opportunity to revise the present diversity in the Guianas. Extensive collections have already been amassed at U. Meanwhile, taxonomic revisions have been

1) Universität Leipzig, Institut für Botanik, Johannisallee 21, 04103 Leipzig, Germany; e-mail: uscharf@uni-leipzig.de.

2) Nationaal Herbarium Nederland, Utrecht University branch, Heidelberglaan 2, 3584 CS Utrecht, The Netherlands; e-mail: p.j.m.maas@bio.uu.nl.

3) Herbier de Guyane, Institut de Recherche pour le Développement (IRD), Boite Postale 165, 97323 Cayenne Cédex, French Guiana (France). 


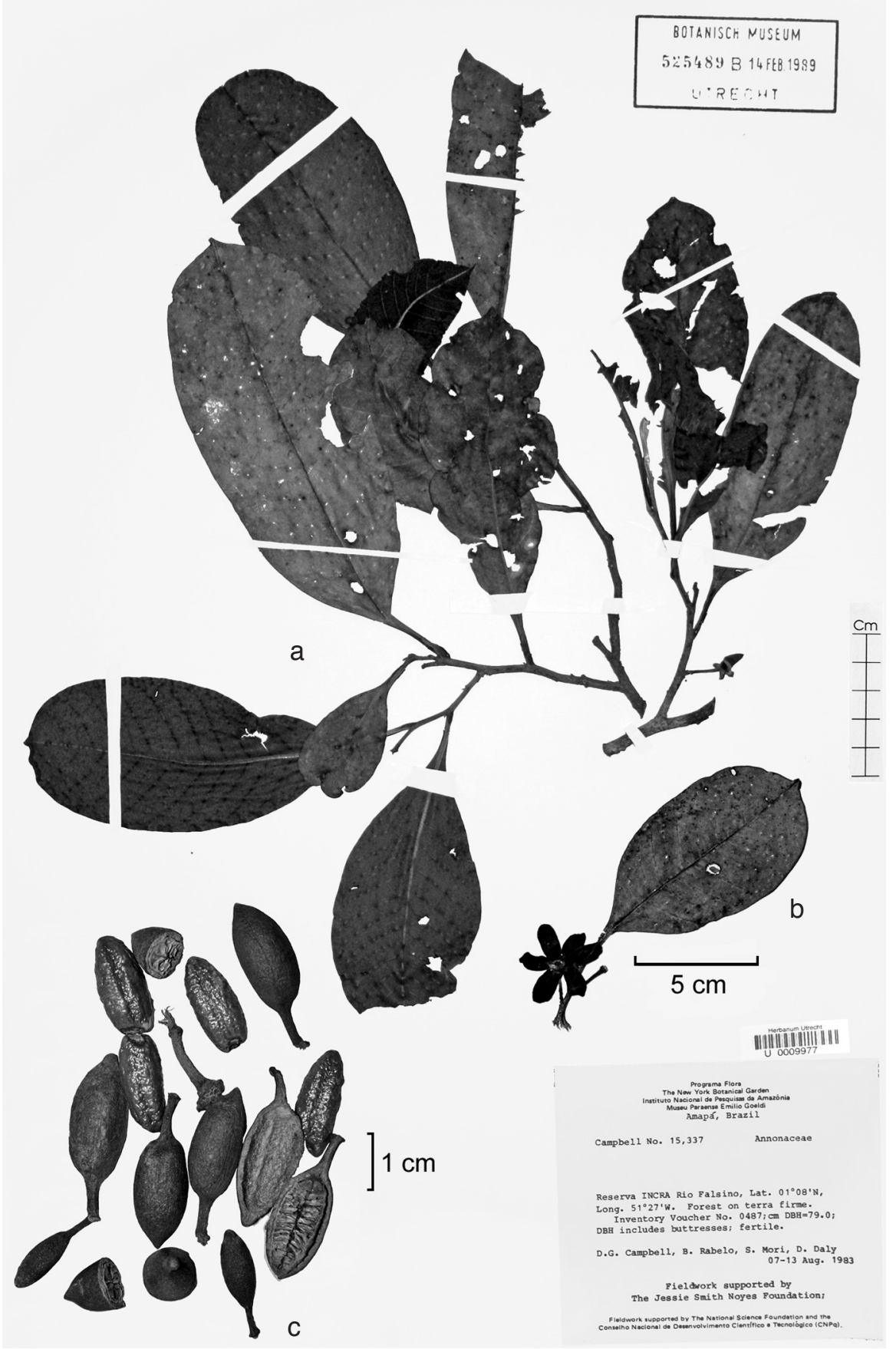

Fig. 1. Guatteria anteridifera Scharf \& Maas. a. Specimen from Brazil, Amapá, Rio Falsino; b. detail of holotype. Twig with flowers and leaves; c. paratype; fruits (a: Campbell 15,337; b: Prévost \& Sabatier 5047; c: Prévost \& Sabatier 4936; all U). Photos U. Scharf. 
undertaken and a number of new species have already been described (Erkens et al. 2006 (Mesoamerica), Erkens et al. 2008 (this Blumea issue p. 465-512, Amazonian Ecuador and Peru), Scharf et al. 2005, 2006a, b (Guianas)). In addition to the large number of specimens of Guatteria already collected in the Guianas over the last 250 years, and deposited in a number of herbaria - particularly that of the Utrecht branch of the National Herbarium of the Netherlands (U), recent discoveries of spectacular trees from this relatively well studied region exemplifies the fact that our knowledge of tropical plant diversity in general is still relatively incomplete. Even huge trees, suitable for timber, have escaped the attention of scientists and foresters.

In this article, a new species of Guatteria from French Guiana and Amapá in Brazil is described. The conspicuous tree trunk of this Guatteria first attracted the attention of the collectors, but all material that could serve as herbarium specimens was located out of reach of any pole-clipper since even the lowest limbs emerge from the trunk at great heights. Climbing the tree was considered dangerous and thus not an option. All material of this species originating from French Guiana, now present in CAY and U, was harvested from the canopy of that exceptionally high $(\sim 40 \mathrm{~m})$ tree with a gun. Only a few individuals of this species are known at this collection site (pers. comm. MFP). However, an as yet nameless pile of mostly sterile collections from a second site in Amapá contained a number of vouchers that also refer to the same species. Remarkable is both the width of the trunk at breast height and the buttresses, features which are also reported for the specimens from French Guiana. This second collection site is about $350 \mathrm{~km}$ away from the original collection site in French Guiana.

\section{Guatteria anteridifera Scharf \& Maas, spec. nov. - Fig. 1-3; Map 1}

Arbor elata G. paludosae R.E.Fr. (1948a: 231) similis sed differt statura plerumque majore et anteridibus conspicuis (nec anteridibus nullis); praeterea laminis minoribus obovatis acumine breviore venis paucioribus, floribus sepalis et staminibus brevioribus, monocarpiis paucioribus sed longioribus, seminibus longioribus distincta. - Typus: D. Sabatier \& M.F. Prévost DS-MFP5047 (holo U; iso CAY), French Guiana, Route Cayenne to Saint Georges, km 122,5, close to Savane Roche Virginie, N 04 $11^{\prime}$ W 52 $09^{\prime}$, flowers, p.p. in alc., 27.7.2006.

Tree, up to $41 \mathrm{~m}$ tall, up to $79 \mathrm{~cm}$ dbh, with buttresses up to $2 \mathrm{~m}$ high and $90 \mathrm{~cm}$ at the base, limbs decurrent. Young twigs densely covered with appressed silvery hairs. Leaves: petioles c. $15 \mathrm{~mm}$ long, 2-3 mm diam., canaliculate, winged; blades obovate, 9-21 cm long, 5.5-8 cm wide, coriaceous, glabrous and dull, greyish to greenish brown, rough (not verrucose) above, dark brown (rarely tinged green) and dull in sicco, sparsely covered with appressed hairs, all over the surface rough (not verrucose) and conspicuously covered by circular structures below, base attenuate, margins revolute, apex acuminate (acumen 3-7 mm long); primary vein impressed and glabrous above, densely covered with straight, appressed, silvery hairs and slightly keeled (carinate) below, secondary veins distinct, $12-14(-16)$ on either side of primary vein, slightly impressed above, angles with primary vein $50-60^{\circ}$, forming a marginal vein, smallest distance between marginal vein and margin 2-3 $\mathrm{mm}$. Flowers axillary and on older branches (ramiflory), 1 in a leaf axil; pedicels 11-14 mm (apical part: c. $12 \mathrm{~mm}$ ) long, c. $2 \mathrm{~mm}$ diam., densely to rather densely covered with appressed silvery hairs, sepals broadly triangular to deltate, $5-6$ by $5-6 \mathrm{~mm}$, outer side densely covered with long 


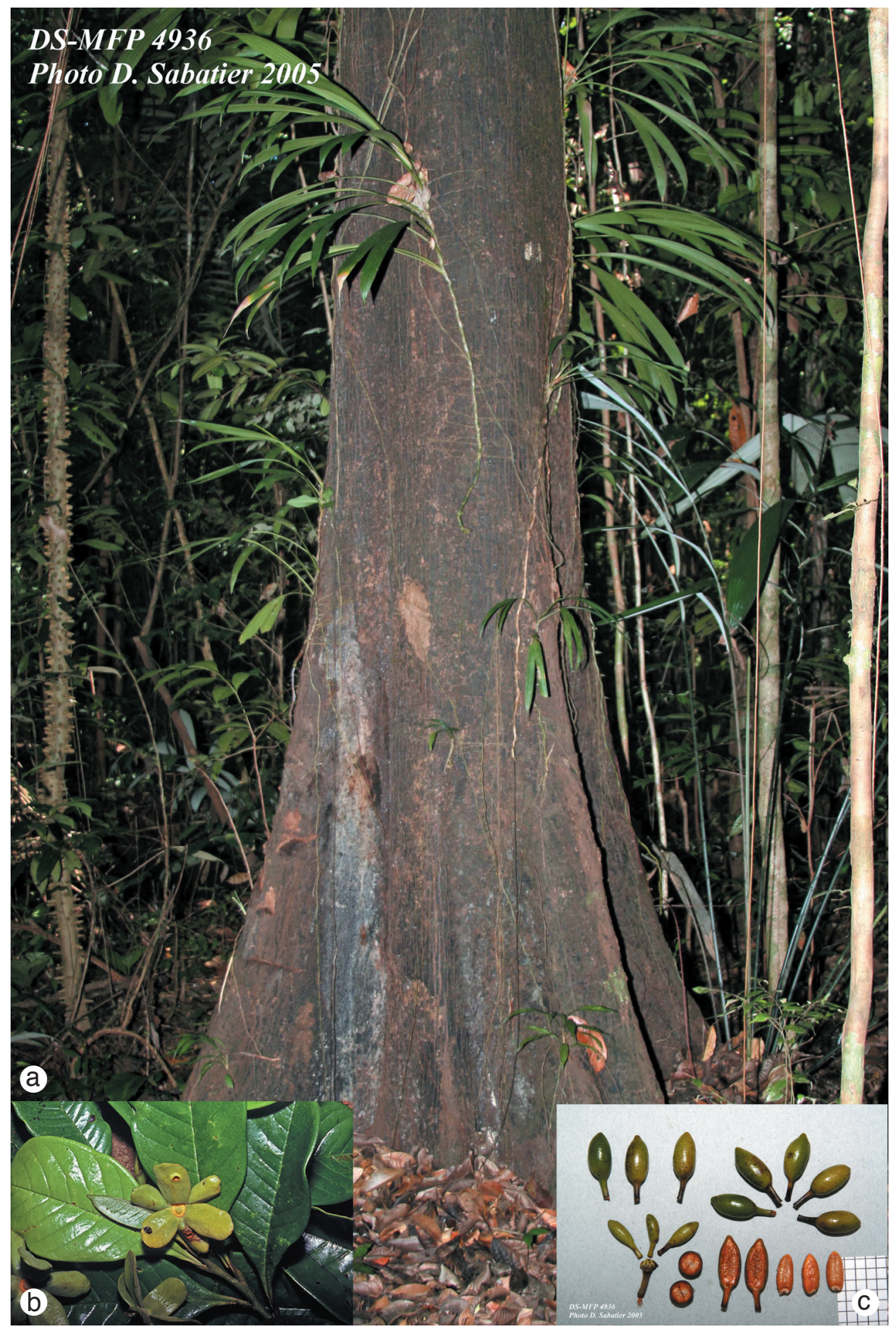

Fig. 2. a. Guatteria anteridifera Scharf \& Maas. Base of trunk with buttresses $2 \mathrm{~m}$ high; b. live twig of holotype with flowers and leaves before preservation; c. paratype; fruits before preservation (b: Prévost \& Sabatier 5047; c: Prévost \& Sabatier 4936; all U). Photos a \& c by D. Sabatier; b by M.F. Prévost. 


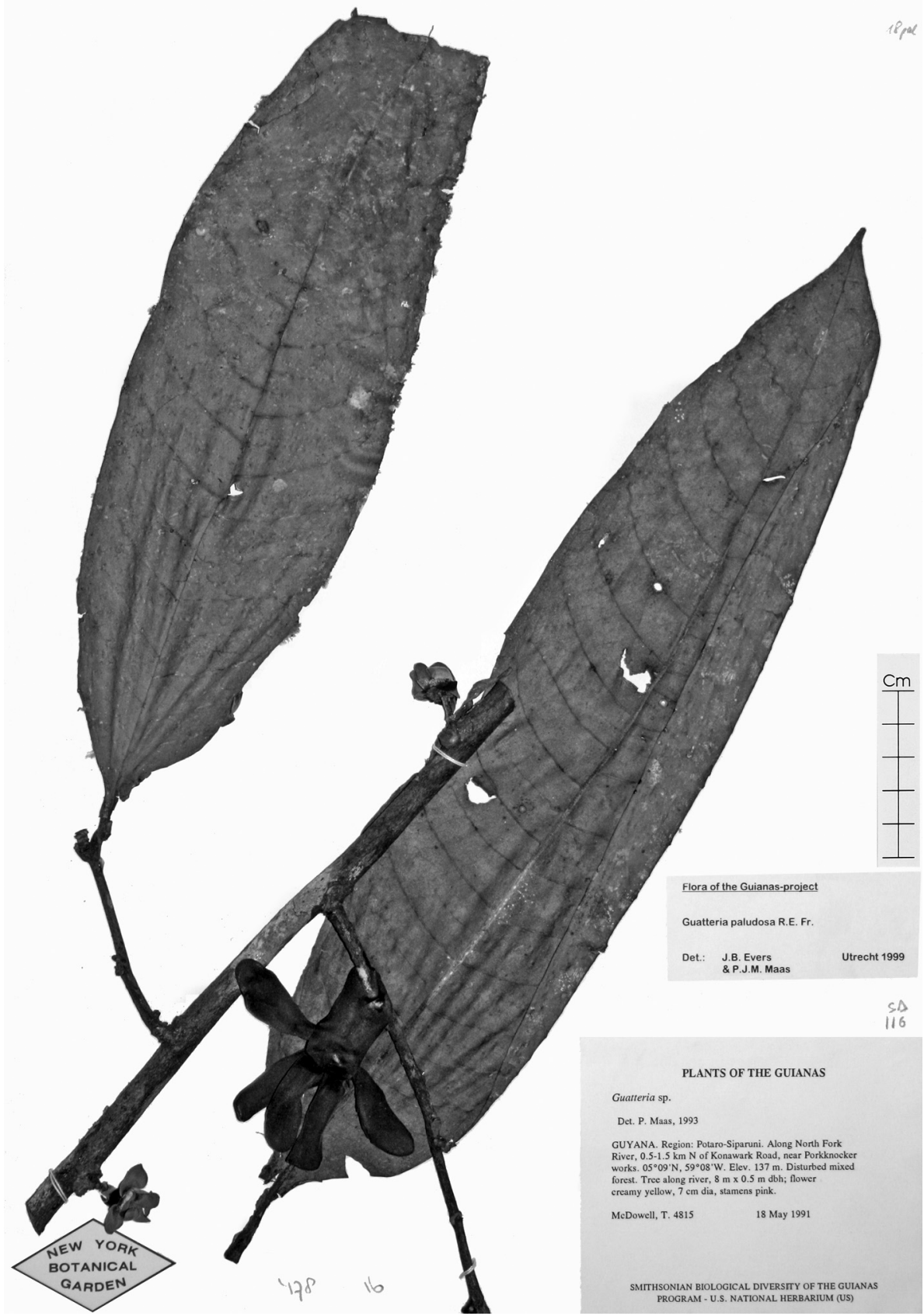

Fig. 3. Guatteria paludosa R.E.Fr. Morphologically the closest species (McDowell 4815, NY). Photo U. Scharf. 


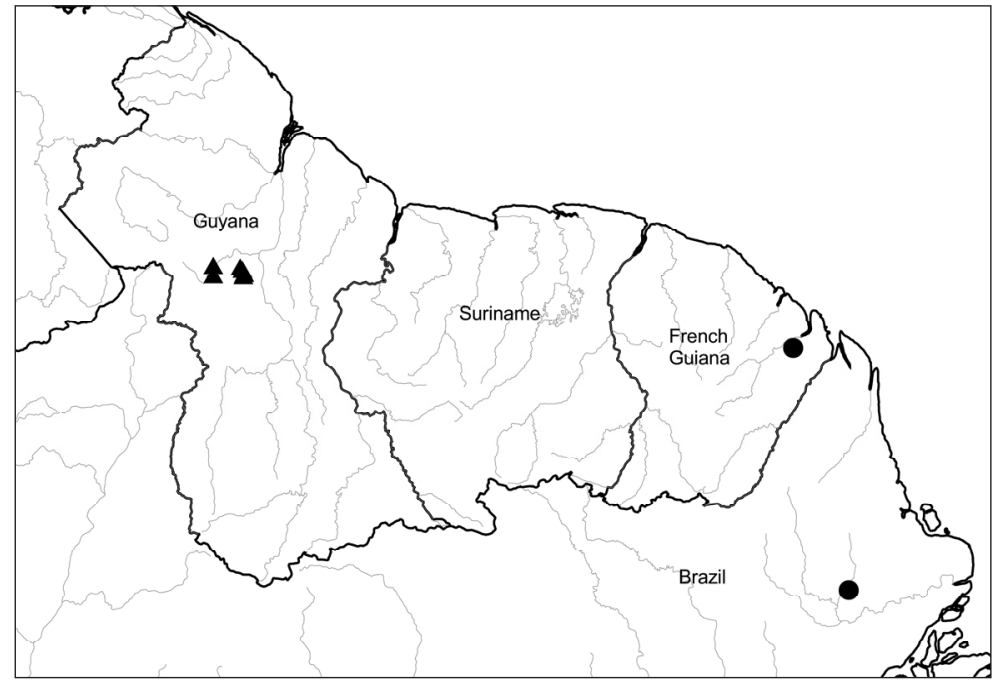

Map 1. Distribution Guatteria anteridifera Scharf \& Maas (๑) and G. paludosa R.E. Fr. (४). Drawing R.H.J. Erkens.

appressed silvery hairs, apically (tips) reflexed, hook-like; petals yellowish green in vivo, petals subequal, elliptic or oblong-elliptic to obovate, $21-23$ by $10-13 \mathrm{~mm}$ (immature), densely covered with short appressed silvery hairs, stamens pale orangebrown, 90-120, c. $1 \mathrm{~mm}$ long, connective shield umbonate, densely hairy; carpels black, 30-50. Monocarps c. 4, green in vivo (immature), greyish to blackish brown in sicco, ellipsoid, 20-22 mm long, c. $10 \mathrm{~mm}$ wide, apex acute and apiculate, glabrous, apex sparsely covered with some appressed hairs, stipes 5-8 $\mathrm{mm}$ long, c. $2 \mathrm{~mm}$ wide. Seeds ellipsoid, 18-19 by 8-9 mm wide, satiny shiny light brown, rough, with shallow furrows from base to apex and a white roundish ovate hilum (c. 5 by $4 \mathrm{~mm}$ ).

Distribution - To date, only known from two collection sites, in French Guiana (2 collections studied) and Brazil, Amapá (7 collections studied).

Ecology - Primary forest.

Phenology - Flowers in July; fruits in November.

Etymology - The new species name is derived from the conspicuous buttresses, which are unusual within the genus Guatteria.

Notes - 1. Superficially, G. anteridifera is similar to G. brevicuspis R.E.Fr. from sect. Mecocarpus. According w3tropicos (Missouri Botanical Garden 2008) G. brevicuspis is also known from marginal Amazonian Peru (Loreto, Madre de Dios), Bolivia (Beni, La Paz), and Ecuador (Napo, Sucumbios), next to the type locality in Brazil, Acre, Rio Purus, avoiding the central part of Amazonia. The shortest linear distance between the type locality of G. brevicuspis and the site in French Guiana measures about $2500 \mathrm{~km}$. Moreover, the conspicuous warts on both sides of the leaf in G. brevicuspis showed a clear difference to the new species. For both reasons a closer relationship could be excluded.

2. Following the key of Fries (1939) determination ends in sect. Leiophyllum, but neither G. scandens nor G. wachenheimii is the right name. The structure of the leaf 


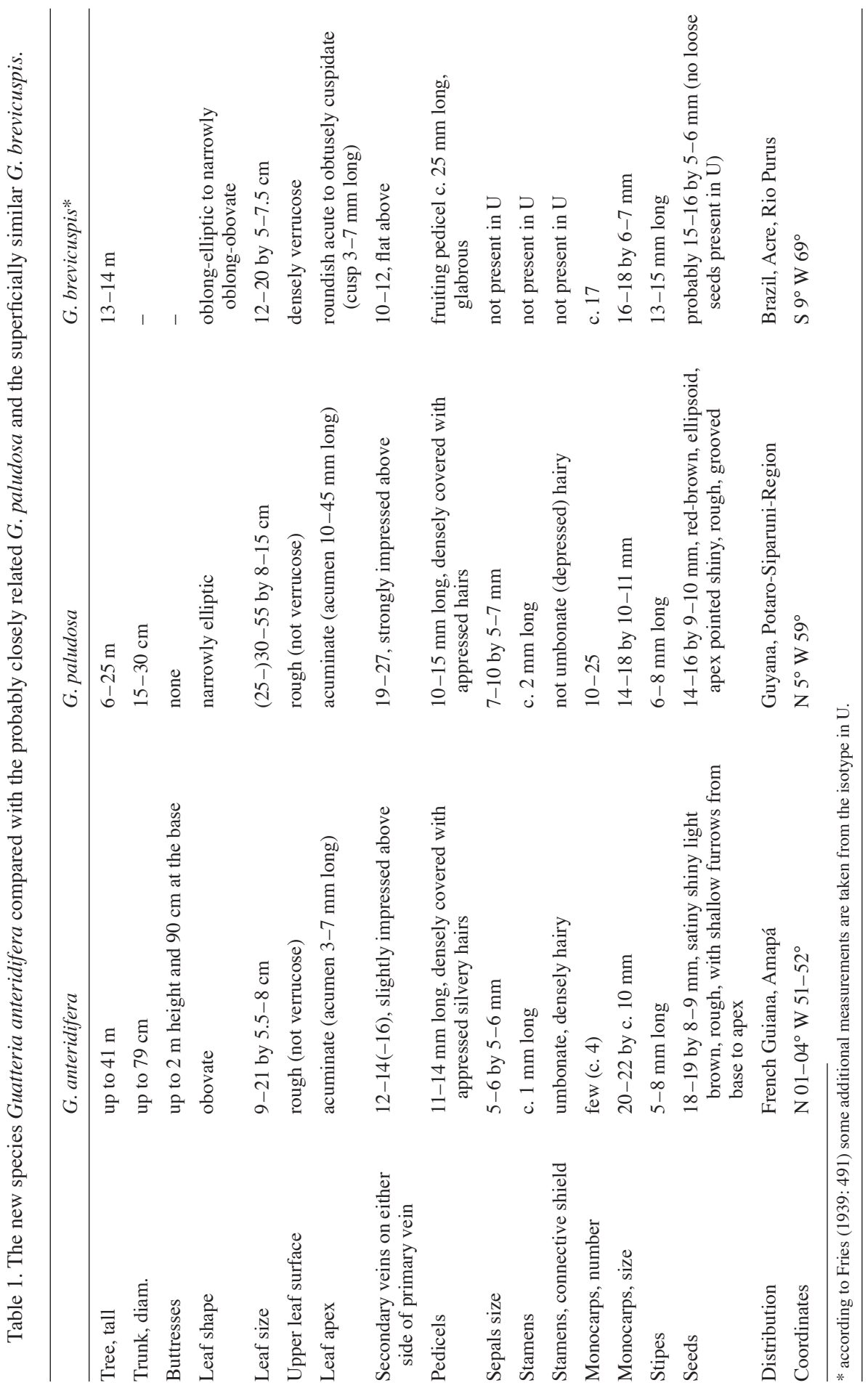


surface (not verrucose but covered by tiny circular structures) is very similar to that of the species G. paludosa R.E.Fr. (1948: 231) which is known in about 800 km distance from Guyana only and represents possibly the closest relative within the genus. Guatteria anteridifera is different from $G$. paludosa by being a generally larger tree with conspicuous buttresses; the blades are smaller and obovate and bear a shorter acumen and fewer secondary veins; the flowers have shorter sepals and shorter stamens; monocarps are less, but longer, the seeds longer (Table 1).

Paratypes (8 collections examined):

FRENCH GuianA. Route Cayenne to Saint Georges, km 122,5, close to Savane Roche Virginie, N 0411' W 5209', fruits, 13.11.2005, D. Sabatier \& M.F. Prévost DS-MFP4936 (CAY, U).

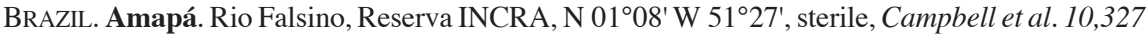
(U), Campbell et al. 14,256 (U), Campbell et al. 14,805 (U), Campbell et al. 14,844 (U), Campbell et al. 14,948 (U), Campbell et al. 15,128 (U), flowers, Campbell et al. 15,337 (U).

\section{ACKNOWLEDGEMENTS}

The work resulting in this publication was carried out in the context of the Flora of the Guianas project, a critical treatment of the plant taxa occurring in the Guianas, and forms a contribution to Flora Neotropica in close cooperation between the Universität Leipzig, Germany, Herbarium LZ and the Nationaal Herbarium Nederland, Utrecht University branch (U). The Latin diagnosis was translated by Lubbert Y.Th. Westra. Special thanks to Daniel Sabatier (CAY) who shot the specimens out of the crown of that exceptionally high tree and Roy H.J. Erkens for constructive discussions and providing the distribution map. The research was only possible by loans and duplicates sent from AAU, B, BBS, BM, BR, BRG, C, CAY, F, FDG, K, MO, NY, P, S, and US. All colleagues involved are gratefully acknowledged.

\section{REFERENCES}

Boggan, J., V. Funk, C. Kelloff, M. Hoff, G. Cremers \& C. Feuillet. 1997. Checklist of the plants of the Guianas (Guyana, Surinam, French Guiana). 2nd ed. Biological Diversity of the Guianas Program, National Museum of Natural History, Smithsonian Institution, publication number 30 , Washington.

Erkens, R.H.J. 2007. From morphological nightmare to molecular conundrum. Phylogenetic, evolutionary and taxonomic studies on Guatteria (Annonaceae). PhD thesis, Universiteit Utrecht, Nationaal Herbarium Nederland.

Erkens, R.H.J., P.J.M. Maas, L.W. Chatrou, G.E. Schatz \& N. Zamora. 2006. Seven taxonomic discoveries in Annonaceae from southeastern Central America. Blumea 51: 199-220.

Erkens , R.H.J., L.Y.Th. Westra \& P.J.M. Maas. 2008. Increasing diversity in the species-rich genus Guatteria (Annonaceae). Blumea 53: 467-514.

Fries, R.E. 1939. Revision der Arten einiger Annonaceen-Gattungen. V. Acta Horti Berg. 12: 289 577.

Fries, R.E. 1941. Neue amerikanische Annonaceen. Acta Horti Berg. 13: 103-116.

Fries, R.E. 1948a. Contributions to the flora of tropical America XLVII. Annonaceae new to British Guiana. Kew Bull. 1948: 229-235.

Fries, R.E. 1948b. New or noteworthy Annonaceae from tropical America. Kungl. Svenska Vetenskapsakad. Handl., ser. 3, 24, 10: 3-19.

Fries, R.E. 1952. Annonaceae. In: R.S. Cowan et al., Plant explorations of G. Wilson-Browne, S.J., in British Guiana. I. Kanuku Mountains. Brittonia 7, 5: 395-396.

Fries, R.E. 1953. Contributions to the flora of tropical America LIV. New trees and shrubs from British Guiana. Kew Bull. 1952: 255-257.

Fries, R.E. 1955. Verstreute Beobachtungen hinsichtlich der Familie Annonaceae. Ark. Bot. n.s., 3: $35-42$. 
Fries, R.E. 1959. Annonaceae. In: H. Melchior (ed.), Die natürlichen Pflanzenfamilien ... begründet von A. Engler und K. Prantl: 1-171. Duncker \& Humboldt, Berlin.

Hollowell, T., P. Berry, V. Funk \& C. Kelloff. 2001. Preliminary checklist of the plants of the Guiana shield. Volume 1: Acanthaceae-Lythraceae. Biological Diversity of the Guianas Program, National Museum of Natural History, Smithsonian Institution, publication number 57, Washington.

Jansen-Jacobs, M. 1976. Annonaceae. In: A.A. Pulle, Flora of Suriname. Additions and corrections to Vol. II, Part 1-2: 658-687. Foundation van Eedenfonds, Leiden.

Johnson, D.M. \& N.A. Murray. 1990. New species of Guatteria (Annonaceae) from the Guayana Highland. Ann. Missouri Bot. Gard. 77: 598-600.

Maas, P.J.M. \& H. Maas-van de Kamer. 2002. Annonaceae (Custard-apple family). In: S.A. Mori, G. Cremers, C.A. Gracie, J.-J. de Granville, S.V. Heald, M. Hoff, J.D. Mitchell (eds.), Guide to the vascular plants of Central French Guiana. Part 2. Dicotyledons. Mem. New York Bot. Gard. 76: 53-67. The New York Botanical Garden Press, New York.

Missouri Botanical Garden 2008. w3tropicos. - http://mobot.mobot.org/W3T/Search/vast.html

Ribeiro, J.E.L.S., P.J.M. Maas, H. Maas \& J.M. Miralha. 1999. Annonaceae. In: J.E.L.S. Ribeiro et al., Flora da Reserva Ducke: 121-135. INPA, Manaus.

Scharf, U., P.J.M. Maas \& W. Morawetz. 2005. Five new species of Guatteria (Annonaceae) from the Pakaraima Mountains, Guyana. Blumea 50: 563-573.

Scharf, U., P.J.M. Maas \& W. Morawetz. 2006a. Five new species of Guatteria (Annonaceae) from the Guianas. Blumea 51: 117-130.

Scharf, U., P.J.M. Maas \& W. Morawetz. 2006b. Guatteria richardii (Annonaceae) rediscovered along with two new species from French Guiana. Blumea 51: 541-552.

Steyermark, J., P.J.M. Maas, P.E. Berry, D.M. Johnson, N.A. Murray \& H. Rainer. 1995. Annonaceae. In: P.E. Berry, B.K. Holst \& K. Yatskievych (eds.), Flora of the Venezuelan Guayana. Vol. 2: 413-469. Missouri Botanical Garden, St. Louis. 